\title{
Dombi G., Horváth Á., Kabai G., Fodor-Kun E., Oláh M., Sápi Z., Szabó P., Tóth B. I. (2017): A területi tőke és magyarországi dimenziói (Nyilvánosságért és Civil Társadalomért Alapítvány, Balatonfüzfö, 424 o.)
}

\author{
FEKETE KÁROLY
}

\begin{abstract}
FEKETE Károly: geográfus kutató, kutatásszervező, Balatoni Integrációs Közhasznú Nonprofit Kft. Társadalomtudományi Kutatócsoport, 8230 Balatonfüred, Lóczy Lajos u. 62.; karoly.fekete@balatonregion.hu
\end{abstract}

Károly FEKETE: geographer, researcher, Lake Balaton Development Coordination Agency, Unit of Social Sciences; Lóczy Lajos u. 62., H-8230 Balatonfüred, Hungary; karoly.fekete@balatonregion.hu

Tekintélyes feladatra vállalkozott a közgazdászokból, geográfusokból, szociológusokból, kulturális antropológusokból, politológusokból álló kutatócsoport, amikor az OECD által több mint másfél évtizede megfogalmazott, a térbeli jelenségek okaira és magyarázataira vonatkozó „,valami van a levegőben” gondolattal indította a területi tőke hazai dimenzióinak vizsgálatát. A területi tőke sokdimenziós kérdéskör, kutatása intellektuális, progresszív kihívás. A társadalmi működés térbeli jelenségeit és törvényszerüségeit vizsgáló kutatókat azok a mélyben megbúvó oksági kapcsolatok megismerése mozgatja leginkább, melyeket egzakt módon megragadni nem, vagy csak innovatív eszköztár segítségével sikerülhet. A területi elemzések számos esetben rámutattak a téregységek olyan fejlettségbeli különbségeire, melyek oksági viszonyrendszere a fejlődési pályák kurrens mutatóival nem voltak kimutathatók. A statisztikai adatfelvételek korlátossága miatt jól körülhatárolható vagy kvantifikált magyarázatunk bizonyos jelenségek mélyben meghúzódó okairól nem is lehetnek. Mégis, hogyan kerülhetünk közelebb a megoldáshoz? Hogyan határozhatjuk meg, hogy mi is egy-egy térelem lényege, mi van az adott hely vagy téregység „levegőjében”?

Már e ponton fontos megjegyezni, hogy a kötet vállalása nem az volt, hogy a fenti kérdésekre a területi tőke koncepciójának Magyarország településeire és járásaira vonatkozó adaptációjával precíz válaszokat adjon. A kutatócsoport a területi tőke módszertani eszköztárát vizsgálta abból a szempontból, hogy a hagyományos módon számszerüsíthető, valamint a nehezen kvantifikálható társadalmi dimenziókat lehet-e széles körben felhasználható, innovatív indikáto-

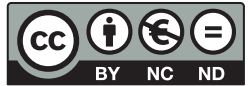


rokkal területi elemzésben megragadni. Emellett a területi tőke országos és települési mintázatait új változókészlettel és széles körű módszertani arzenállal tárták fel.

A különböző tudományterületekről érkező és eltérő tapasztalatokkal rendelkező szakemberekből álló szerzőgárda a fogalmak tisztázásával indította a téma kidolgozását az első fejezetben. A hazai és a nemzetközi szakirodalom segítségével foglalkoztak a térbeliség fogalmának, a hagyományos és újszerü tőkeértelmezéseknek, tőkefajtáknak, tőketényezőknek témakörével, valamint a területi tőke értelmezésével. Megkísérelték a területi tőke fogalmának - korábbi értelmezéseken túlmutató - definiálását, amely szerint a területi tőke „a térbeli együttességből eredően egymással különböző kombinációkat, s így egyedi struktúrákat alkotni képes endogén jellegű tényezők összessége".

A 2. fejezet szintén a tematikus megalapozást szolgálja, ebben ismertették a területi tőke kutatásának hazai és nemzetközi publikációit, céljait, módszertanait és eredményeit. A módszerek között szerepel a leggyakrabban alkalmazott faktoranalízis és klaszteranalízis, az ezek alapján kidolgozott többváltozós (elsősorban területi, forráskihelyezési szempontú) elemzések, valamint a területitőke-kutatásokban nóvumként megjelenő ingatlanérték-elemzés. A kvantitatív elemzések az ország egészére készültek, települési, illetve indokolt esetben járási szinten, ami a fejlesztéspolitika számára is hasznos lehet. A kérdőíves vizsgálatra építő kvalitatív elemzés a Balaton Kiemelt Üdülőkörzet két járására készült el.

A kötet 3. fejezete átfogó fejlesztéspolitikai kontextusba helyezi a területi tőkét európai uniós, valamint hazai léptékben. Bár az Európai Unió szorgalmazza a területfejlesztésben a helyalapú megközelítést, a közösségi források elosztását központosított tematikus célok és stratégiai célrendszer határozzák meg.

A 4. fejezet a területi tőke kvantitatív vizsgálatával foglalkozik Magyarországon. A szerzők szándéka az volt, hogy minél szélesebb változókészletet állítsanak össze, tekintettel arra, hogy az újszerü mutatók tesztelését a területitőke-koncepció lehetővé teszi, sőt igényli. Így a 156 mutató közé ritkán alkalmazott, progresszív elemzői szemléletet tükröző változók is bekerültek, például a települések természetes és mesterséges vízparthossza, a legutolsó országgyülési választások részvételi adatai vagy a polgármester-aspiránsok településenkénti száma. A viták során a mintázatba nem illeszkedő mutatókat transzparens eljárások keretében eltávolították, így végül 77 mutatóval készült el az elemzés.

A faktor- és klaszteranalízis egyik legfontosabb következtetése, hogy a területi tőke települési szintű immateriális összetevői (kapcsolati, humán, társadalmi, illetve kulturális tőkeelemek) nagymértékben árnyalják az országos területi mintázatot, így a területi tervezésben, programozásban és monitoringban jóval nagyobb szerepet indokolt adni az immateriális tőkeelemeknek. A klaszteranalízis általánosságban jól kirajzolja az országos térszerkezetet, a közismert strukturális anomáliákat és problémákat (pl. a képzettség hiánya, az internetelérhetőség hiányosságai, az egészségügyi ellátás és oktatás jellemzői). Az eredmények értelmezhetőségét segítette volna, ha mind a materiális, mind az immateriális tőkekomponensekből kialakított klasztereket megnevezték volna. 
Meglehetősen izgalmas és az egész kutatómunka fő kérdésfeltevései kapcsán is lényeges témakör a klaszterszerkezetbe valamilyen egyedi helyi jelenség miatt nem illeszkedő településhalmaz. Nem elvárható, hogy minden ilyen település oksági viszonyrendszerét mélységében vizsgálja a kutatás, azonban elképzelhető, hogy pontosan ezen kiugró településeknél azonosíthatók olyan endogén jellegzetességek, melyek éppen arra a kérdésre adhatnak választ, hogy mi az az adott téregység levegojében, amelytől az egyedi struktúra létrejöhet. Így - akár esettanulmány-jelleggel - indokolt lehet az eredmények további, a helyi specifikumokat konkretizáló továbbvitele. A szerzők szerint az elkészült modell lehetőséget ad arra, hogy abból települési, járási szintű mélyfúrások készülhessenek.

A kötet 4.2.4 fejezete a települési szintü materiális és immateriális tőkekomponensekből készült faktoranalízis eredményeit szemlélteti. Fontos megjegyezni, hogy egyrészt a grafikus ábrázolás számos területi sajátosságra hívja fel a figyelmet, másrészt a függelékben felsorolt települési szintű tőkekomponensátlagok és azok térképi ábrázolása a munka laikusok számára is értelmezhető kézzel fogható eredményét, közhasznát hivatott igazolni.

Külön fejezet foglalkozik a lakóingatlanárak területi jellemzőivel, ami szintén a kutatómunka progresszív közelítését erősíti. Azon túlmenően, hogy az ingatlanpiaci fejezet önálló elemzésként is megállja a helyét, a területitőkekoncepciót tovább erősíti, hogy a térségek és települések egyedi jelenségeit az immateriális elemekkel hangsúlyosabban figyelembe veszi, mint azt a hagyományos szemléletű területi elemzések és hatásvizsgálatok - elsősorban fejlesztéspolitikai - eszköztára számba veszi.

Az 5. fejezet a társadalmi tőke jellemzőit elemzi a fonyódi és a keszthelyi járásban. A társadalmi kapcsolatok, a bizalom, a területi kötődés és identitás szerepét a területi tőke vonatkozásában vizsgáló esettanulmány újszerü közelítésben veti össze két járás társadalmi tőkeelemeit, a helyi politikai és gazdasági elitre fókuszálva. A településvezetőkkel folytatott interjúk kirajzolják a vidéki Magyarország helyi politikai elitjének attribútumait és meghatározottságát, a sok tényező által beszúkített mozgásteret, a kapcsolati tőke kiemelt szerepét, a centralizált államszervezet végeken megnyilvánuló bizalmi struktúráit. Nagy kérdés ugyanakkor, hogy a kérdőíves felmérés során valóban sikerült-e a helyi és járási gazdasági működést és teljesítményt meghatározó vállalkozói kört megszólítani. Tudhatjuk, hogy a Balaton Kiemelt Üdülőkörzetben jelenleg is zajlik egy gazdasági elitcsere, másképpen fogalmazva térfoglalás, melynek fó aktorai alapvetően nem a helyi társadalomból kerülnek ki, hanem egy kívülről érkező befektetői körből (bár ez semmiképpen sem új keletű jelenség). Mindenképpen üdvös lenne, ha a későbbiekben több hasonló esettanulmány készülne el, járási, közigazgatási, funkcionális térségi, netán országos szinten.

A kötet vállalása ambiciózus, hiszen amellett, hogy a lehető legteljesebben kívánja bemutatni a területi tőke fogalmi kereteit, tudománytörténeti aspektusait, módszertani alkalmazhatóságát, valamint - különböző területi szinteken - mérhető magyarországi dimenzióit, a területpolitikai döntés-előkészítés számára is 
felhasználható alternatív elemzési modellt vagy eszköztárat kíván összeállítani. Habár a kötet szerzői a lehető legrészletesebben, szinte kézikönyvjelleggel dokumentálják az általuk alkalmazott módszertani lépéseket, azok részletes, okokozati összefüggéseit, az eszköztár első közelítésben és jelen formájában nehezen adaptálhatónak tűnik a hazai fejlesztéspolitika stratégiai tervezésébe. Ennek egyik oka, hogy a többváltozós matematikai-statisztikai módszereket integráló területitőke-vizsgálatok szakértőket igényelnek, a kvalitatív vizsgálatok pedig jelentős személyi kapacitást. Nem szabad elfelejteni a hazai döntés-előkészítés egyik rákfenéjét sem, az időtényezőt: részben vagy egészben a bemutatott módszertan szerint készülő területi elemzések és hatásvizsgálatok csak megfelelő ütemezettséggel és forrásokkal állhatnak elő.

Szakmai diskurzusokra érdemes, de alapvetően alkalmazhatósági dilemma lehet továbbá, hogy bár a döntéshozók munkáját megkönnyítheti, ha egy-egy számértékbe próbáljuk belesűríteni téregységek és települések széles spektrumot átölelő jellemzőit, e tekintetben vajon valós és megalapozott alternatíva-e a területi tőke. A tőkekomponensek főátlagai által megrajzolt kép megalapozottnak tekinthetö, azonban nagy kérdés, hogy a számos változó által kialakuló árnyalt és összetett kép mennyire mossa el az egyediségeket egy generalizált jelzőszám használatával. Ez pedig egy laikus vagy csak részben érintett szakértő számára megnehezítheti az értelmezést, hiszen meghatározó attribútumok veszhetnek oda a dimenziócsökkentő eljárások és átlagolások folyamán - vagy akár a mutatószámok empirikus kiválasztása során is.

A recenzió végére hagyva a legkönnyedebb témát, a recenzens nem mehet el elismerő szavak nélkül a borító mellett. A kötet fogalmaiból felépített stilizált halmok egyúttal a felhalmozott tőkét jelképezik, melynek változását a halmok porladása jeleníti meg. A borító grafikai kivitelezése kifejezetten korszerü, nem a tudományos irodalomban megszokott, sematikus képi világot alkalmazza. De természetesen nem ezért ajánlott olvasmány e könyv. Hasznos és tanulságokban bővelkedő olvasnivalója lehet a területi tőke kutatóinak, az új szemléletű elemzési irányzatok iránt érdeklődő regionális elemzőknek, a térbeli folyamatok, jelenségek ok-okozati összefüggéseivel foglalkozó geográfusoknak, közgazdászoknak, szociológusoknak, a területpolitika és a széles körben értelmezhető társadalmi-gazdasági szakpolitika döntés-előkészítőinek és döntéshozóinak. Mivel a kutatás sok aspektusból közelítette meg és dolgozta fel a területi tőke jelenségét, akár szemelvényenként is, de feltétlenül ajánlott a kötet oktatási célú felhasználása, elsősorban a területfejlesztés, a regionális elemzés, a regionális és általános közgazdaságtan, valamint a szociológia területén.

A fentieken túl pedig, jövőbe tekintés gyanánt fel kívánom hívni a figyelmet arra, hogy e kötet számos kaput nyitott ki azon az úton, ami oda vezet, hogy megtudjuk, „mi van a levegőben.” Azonban az igazán egzakt válaszokhoz - amennyiben lehet ilyet találni - jó néhány további, hasonló szemléletű, e könyv tanulságait felhasználó, innovatív kutatói-elemzői munkára, valamint mindezt támogató szakpolitikai akaratra lesz szükség. 